\title{
Survival ability of Trichoderma spp and Pseudomonas in Different carrier Materials
}

\author{
M. Paramasivan ${ }^{1} *$, S. Thaveedu ${ }^{1}$, S. Mohan $^{2}$ and N. Muthukrishnan ${ }^{2}$ \\ ${ }^{1}$ Department of Plant Pathology, Dryland Agricultural Research Station, Chettinad, India \\ Agricultural Research Station, Kovilpatti, India \\ ${ }^{2}$ Department of Entomology, Tamil Nadu Agricultural University, India \\ *Corresponding author
}

\begin{tabular}{|l|}
\hline K e y w o r d s \\
Biocontrol, \\
Substrates, \\
Shelflife, Storage, \\
Application
\end{tabular}

A B S T R A C T
The investigation is carried about talc based biocontrol agents for formulation and delivery system for microorganism that enable them for efficient disease control in Soilborne disease. In the present investigation, the carrier materials viz., talc, gypsum, vermiculate, flyash, talc + gypsum, talc + vermiculate, talc + flyash, Talc + Neem cake, Talc+ Decomposed coir pith and Talc + FYM were tested to assess the survival of $T$. viride (TVB1), T. harzianum (THB1) Pseudomonas fluorescens and Bacillus subtilis The results revealed that $T$. viride and $T$. harzianum showed the maximum level of population in talc at the end of $120^{\text {th }}$ Days after storage followed by neem cake, Bacterial antagonist for Pseudomonas fluorescens and Bacillus subtilis showed the maximum level of population in talc at the end of $120^{\text {th }}$ Days after storage followed by Talc + Farmyard Manure

\section{Introduction}

The talc based powder formulations are popular in India and elsewhere, it is used for larger area application using different substrates for multiplication biocontrol agents and increasing shelf life microorganism due integrated disease management with different substrates, longer shelf life, greater protection against environmental stresses and increased field efficacy. The mass production systems should be compatible with industrial and commercial development methods and field application. So formulations of Trichoderma viride required to find out suitable media therefore, the first step for the formulations of any bio-control agent is to identify the suitable substrates, The type and form of substrate i.e. broth and solid may also vary according to the specific purpose for which bio-control agent 
biomass is required. Production of adequate quantities of good quality inoculums is an essential component of the biocontrol programme. Therefore the present study was aimed to find out the storability of Trichoderma viride and Pseudomonas in different formulations with the various substrates. wheat straw, wheat straw dust and sorghum grain-peat-bran (Roiger and Jeffers, 1991). Lewis et al., (1991) developed a bulk type formulation In this system vermiculite containing small amounts of bran was amended with biomass of Gliocladium and Trichoderma and stored dry for as long as 24 weeks. Before use, the dry vermiculite-branbiomass formulation was moistened with dilute acid and incubated for 2 days to allow the fungi to germinate and colonize the substrate Trichoderma viride against Root rot pathogens (Paramasivan et al., 2007), Sangeetha Panickar and Jeyarajan (1993) used different substances like rice bran, wheat bran, peat soil, farm yard manure (FYM) and rice straw and they reported that the FYM and wheat bran were the best substrates for mass multiplication of Trichoderma spp.. Prasad and Rangeshwaran (1999) studied the modified granular formulation containing powdered wheat bran, kaolin, acacia powder and biomass of isolates of $T$. hamatum, $T$. virens and G. aeliguescens. Granules with all isolates of bioagents significantly reduced the damping-off in chickpea. The storage of bioagent $T$. harzianum promoted initial growth $\left(10^{7.6}\right.$ to $\left.10^{8.5} \mathrm{cfu} \mathrm{g}^{-1}\right)$ of the fungus upto 30 days and the population declined thereafter but retained substantial number of viable propagules even at 90 days (Prasad and Rangeshwaran, 2000).

Selvakumar et al., (2001) studied the various substances viz., coirpith, maize cob medulla, peat, saw dust, talc powder and wheat bran for the mass multiplication of C. globosum and they reported that peat soil was found to be the best in supporting the growth of C. globosum $\left(7.2 \times 10^{8} \mathrm{cfu} \mathrm{g}^{-1}\right)$. Ali et al., (2001) tested the survival period of Pseudomonas aeruginosa on mungbean seed coated with different carriers / substrates and was found best on the talc amended with CMC. On all substrates the antagonists population were declined dramatically at 120 days after coating.

Sivakumar et al., (2000) tested different carrier substrates viz., talc powder, blackgram shell, coir pith, peat, shelled maize cob. Among these carriers, peat and talc were found to maintain the population at $19.5 \times 10^{7}$ and $18.3 \times 10^{7} \mathrm{cfu}^{-1}$ of the product respectively after 40 days of storage. Manjula and Podile (2001) developed a formulation supplemented with 6.5 per cent chitin of Bacillus subtilis (AF 1) effectively reduced Aspergillus niger and Fusarium udum caused crown rot of groundnut and wilt of Pigeon pea, respectively. Bacillus subtilis AF 1 talc based formulation promoted the seed germination and biomass yield of both crops.

\section{Shelf life of bio control agents}

The efficient bio control agents should possess longer shelf life without losing its efficacy. Shelf life of an antagonist in the substrate is important in commercial production. Talc based formulation of Trichoderma viride retained 50 and $25 \%$ of its initial population after two and four months of storage respectively. Loganathan (2002) reported that talc was found to be best for the survival of Trichoderma spp. and Pseudomonas spp. The Trichoderma spp. survived with required colony forming units $\left(10^{8} \mathrm{cfu} / \mathrm{ml}\right)$ in talc formulation upto 120 days of storage. Both Pf1 and CHAO strains survived with $10^{8} \mathrm{cfu}$ per $\mathrm{ml}$ up to 90 days in talc formulation.

Manav and Singh (2003) tested the shelf life of Trichoderma harzianum for a period of 120 days under wet and dry condition. The wet formulation recorded maximum number of colony forming units than the dry formulation. The low temperature of $8 \pm 2{ }^{\circ} \mathrm{C}$ favoured 
maximum number of propagules (18) than the high temperature of $25 \pm 2{ }^{\circ} \mathrm{C}$ (14).

\section{Materials and Methods}

Isolation and identification of Trichoderma spp and Pseudomonas: The rhizospheric samples were collected randomly from different locations of Tropical sugarbeet ecosystem. Effective Trichoderma spp and Pseudomonas, and Bacillus subtilis against Sclerotium rolfsii under In vitro condtion, these bioagents application with different carrier material tested for field application.

\section{Preparation of talc based formulation bio control agent}

A loop full of $P$. fluorescens and B. subtilis were inoculated into the King's B broth and Nutrient broth and incubated in a rotary shaker at $150 \mathrm{rpm}$ for $72 \mathrm{~h}$ at room temperature $(28 \pm$ $2{ }^{\circ} \mathrm{C}$ ). After $72 \mathrm{~h}$ of incubation the broth containing $9 \times 10{ }^{8} \mathrm{cfu} / \mathrm{ml}$ was used for the preparation of talc based formulation. To 400 $\mathrm{ml}$ of bacterial suspension, $1 \mathrm{~kg}$ of the talc powder, calcium carbonate $15 \mathrm{~g}$ (to adjust the $\mathrm{pH}$ to neutral) and carboxy-methyl cellulose (CMC) $10 \mathrm{~g}$ (as adhesive) were mixed under sterile condition following the method described by Vidhyasekaran and Muthamilan (1999). The products were shade dried to reduce the moisture content to 20 percent and then packed in polypropylene bags and sealed.

\section{Trichoderma sp.}

A mycelial disc $9 \mathrm{~mm}$ of $T$. viride (TVB1) and T. harzianum (THB 1) was inoculated into $100 \mathrm{ml}$ of molasses yeast medium in $250 \mathrm{ml}$ conical flasks and incubated at room temperature for 14 days. The mycelial mat was homogenized and blended with talc powder at 1:2 ratio. Five gram of CMC was added to one $\mathrm{kg}$ of talc and mixed well. The materials were shade dried and packed in polypropylene bags, heat sealed and kept at room temperature (Ramakrishnan et al., 1994).

\section{Survival of antagonists' organism in different carrier materials}

\section{Survival of $\boldsymbol{P}$. fluorescens and $\boldsymbol{B}$. subtilis in different formulations}

Bacterial biocontrol agents were grown in King's $B$ and Nutrient broth for $48 \mathrm{~h}$ at room temperature $\left(28 \pm 2^{\circ} \mathrm{C}\right)$. Survival of the antagonist's bacterium was tested in different formulations. Talc, gypsum, flyash, vermiculate, talc + gypsum (1:1), talc + flyash (1:1), talc+ vermiculate (1:1).Ten gram of carboxy methyl cellulose was added to one $\mathrm{kg}$ of the carrier and mixed well. The $\mathrm{pH}$ of the all materials was adjusted to 7.00 by adding calcium carbonate. The carrier was autoclaved for $30 \mathrm{~min}$ for two consecutive days. Four hundred $\mathrm{ml}$ of the bacterial suspension containing $9 \times 10{ }^{8} \mathrm{cfu} / \mathrm{ml}$ was added to one $\mathrm{kg}$ of the carrier materials and mixed well under aseptic conditions. The materials were packed in polythene bags. Sealed and incubated at room temperature $\left(28 \pm 2^{\circ} \mathrm{C}\right)$. After 20 days storage, the samples were drawn at 10 days intervals and the bacterial population was assessed using King's B and Nutrient Agar medium by dilution plate methods.

\section{Trichoderma sp}

$T$. viride and $T$. harzianum were grown in yeast molasses medium and it was incubated for 15 days and then the content was drained. The fungal biomass was removed and this was mixed with $1 \mathrm{~kg}$ of carrier materials at 1:2 ratio. The mixture was shade dried. Carboxy methyl cellulose was added to the carrier material @ $5 \mathrm{~g} / \mathrm{kg}$ of carrier material. The materials were packed in polythene bags. Sealed and incubated at room temperature (28 $\pm 2^{\circ} \mathrm{C}$ ). Storage after 20 days storage the 
samples were drawn at 10 intervals and the Trichoderma spp population was assessed using Trichoderma special medium by dilution plate methods.

Mass multiplication of antagonistic bacteria and Trichoderma in different substrates

The antagonistic bacteria $P$. fluorescens isolate SBHRPF2 and $B$. subtilis isolate SBHRBS1and $T$. viride (TVB1) and $T$. harzianum (THB1) were mixed with at the rate of $10 \mathrm{~g} / \mathrm{kg}$ of sterilized Neemcake, decomposed coir pith and farmyard manure. Moisture content of the farmyard manure was adjusted to 50 per cent. The population of both bacteria and Trichoderma were recorded at an interval of 10 day to assess its shelf life.

\section{Results and Discussion}

\section{Fungal antagonists}

In the present investigation, the carrier materials viz., talc, gypsum, vermiculate, flyash, talc + gypsum, talc + vermiculate, talc + flyash, Talc + Neem cake, Talc+ Decomposed coir pith and Talc + FYM were tested to assess the survival of $T$. viride (TVB1) and T. harzianum (THB1) The results revealed that $T$. viride and $T$. harzianum showed the maximum level of population in talc at the end of $120^{\text {th }}$ Days after storage followed by neem cake (Table 1 and Fig. 1). The population of $T$. viride showed decreasing trend from the initial level population level in the carrier materials viz., Talc + Neem, gypsum, Talc + gypsum (1:1) whereas the population increased up to 20 days after storage from the initial population in case of talc. The population of T.harzianum decreased from the initial population over time in all the carrier material except talc. Where the population increased up to 20 DAS and later it showed a decreasing trend. Paramasivan et al., (2013) stated that the
Rhizosphere Trichoderma sp against Sclerotium rolfssi in tropical sugarbeet and was recorded in Trichoderma talc formulation 3 months of rhizosphere and declined in nature. The earlier work by Jeyarajan et al., (1994) explained that the talc based formulation and vermiculite wheat bran based formulation of $T$. viride could be safely stored from 75 to 120 days at room temperature. Loganathan (2002) reported that talc based formulation was best over other carriers tested and retained required cfu until120 and 90 days in Trichoderma and Pseudomonas sp. respectively.

\section{Bacterial antagonists}

The results revealed that the population level of P. fluorescens (SBHRPF2) and B. subtilis (SBHRBS1) was the maximum in talc followed by Talc+FYM, vermiculate at the end of 120 days after storage. The population level showed decreasing trend in the carrier materials viz., talc + gypsum, talc + vermiculate, talc + flyash, and Decomposed coir pith. Whereas the population increased upto 20 days from the initial population, later it showed decreasing trend (Table 2 and Fig. 2).

Vidhyasekaran and Muthamilan (1995) developed a talc-based formulation of $P$. fluorescens for controlling chickpea wilt. The carrier materials viz., peat and talc maintained the population level of the antagonists up to 40 days of storage (Siva Kumar et al., 2000). Sangita Bapat and Shah (2000) reported that a formulation of B. brevis with vermiculite as a carrier had a shelf life of at least six months.

The development of the powder formulation of the bacteria, with a shelf life of more than eight months may be highly useful for large scale field application of the product and effective control of the diseases (Vidhyasekaran and Muthamilan, 1999). 
Table.1 Survivals of $T$. harzianum in different carrier materials

\begin{tabular}{|c|c|c|c|c|c|c|c|c|c|c|}
\hline \multirow{3}{*}{$\begin{array}{c}\text { S. } \\
\text { No }\end{array}$} & \multirow[t]{3}{*}{ Carrier materials } & \multicolumn{9}{|c|}{ *Survival of $T$. harzianum in carrier materials $10^{3} \mathrm{CFU} / \mathrm{g}$} \\
\hline & & \multicolumn{9}{|c|}{ Number of Days (21 Days after) } \\
\hline & & $\mathbf{0}$ & 20 & 30 & 40 & 50 & 60 & 70 & 80 & 90 \\
\hline 1 & Talc & 50.00 & 48.20 & 42.50 & 42.50 & 40.50 & 38.75 & 36.76 & 34.00 & 30.33 \\
\hline 2 & Gypsum & 46.50 & 42.50 & 40.00 & 37.50 & 34.00 & 30.50 & 26.50 & 23.00 & 14.33 \\
\hline 3 & Flyash & 38.50 & 35.50 & 34.00 & 27.00 & 23.50 & 19.50 & 16.50 & 14.30 & 10.00 \\
\hline 4 & Vermiculate & 38.00 & 35.26 & 33.50 & 30.75 & 27.50 & 23.50 & 19.50 & 16.50 & 9.00 \\
\hline 5 & Talc + Gypsum & 49.50 & 50.00 & 43.50 & 40.50 & 38.50 & 36.75 & 31.50 & 28.50 & 20.50 \\
\hline 6 & Talc +Flyash & 45.50 & 41.26 & 39.00 & 37.50 & 33.50 & 30.33 & 24.50 & 20.50 & 13.00 \\
\hline 7 & Talc +Vermiculate & 39.50 & 38.50 & 37.56 & 35.50 & 30.50 & 27.50 & 20.75 & 17.50 & 11.50 \\
\hline 8 & Talc + Neem cake & 48.00 & 49.50 & 43.50 & 40.50 & 37.00 & 35.50 & 30.75 & 26.50 & 18.50 \\
\hline 9 & $\begin{array}{l}\text { Talc + Decomposed } \\
\text { coir pith }\end{array}$ & 40.50 & 34.50 & 31.50 & 29.50 & 24.00 & 20.00 & 17.50 & 15.40 & 7.50 \\
\hline 10 & Talc + FYM & 44.00 & 41.50 & 40.50 & 38.50 & 35.50 & 30.25 & 27.50 & 24.50 & 15.00 \\
\hline \multicolumn{11}{|c|}{$\begin{array}{l}\text { *Mean of three replications } \\
\mathrm{CD}(\mathrm{P}=0.5)\end{array}$} \\
\hline $\begin{array}{l}\text { Carr } \\
\text { Day } \\
\text { Carr }\end{array}$ & materials x Days & $\begin{array}{l}0.878 \\
0.878 \\
2.779\end{array}$ & & & & & & & & \\
\hline
\end{tabular}

Fig.1 Survival of biocontrol agents in different carrier materials

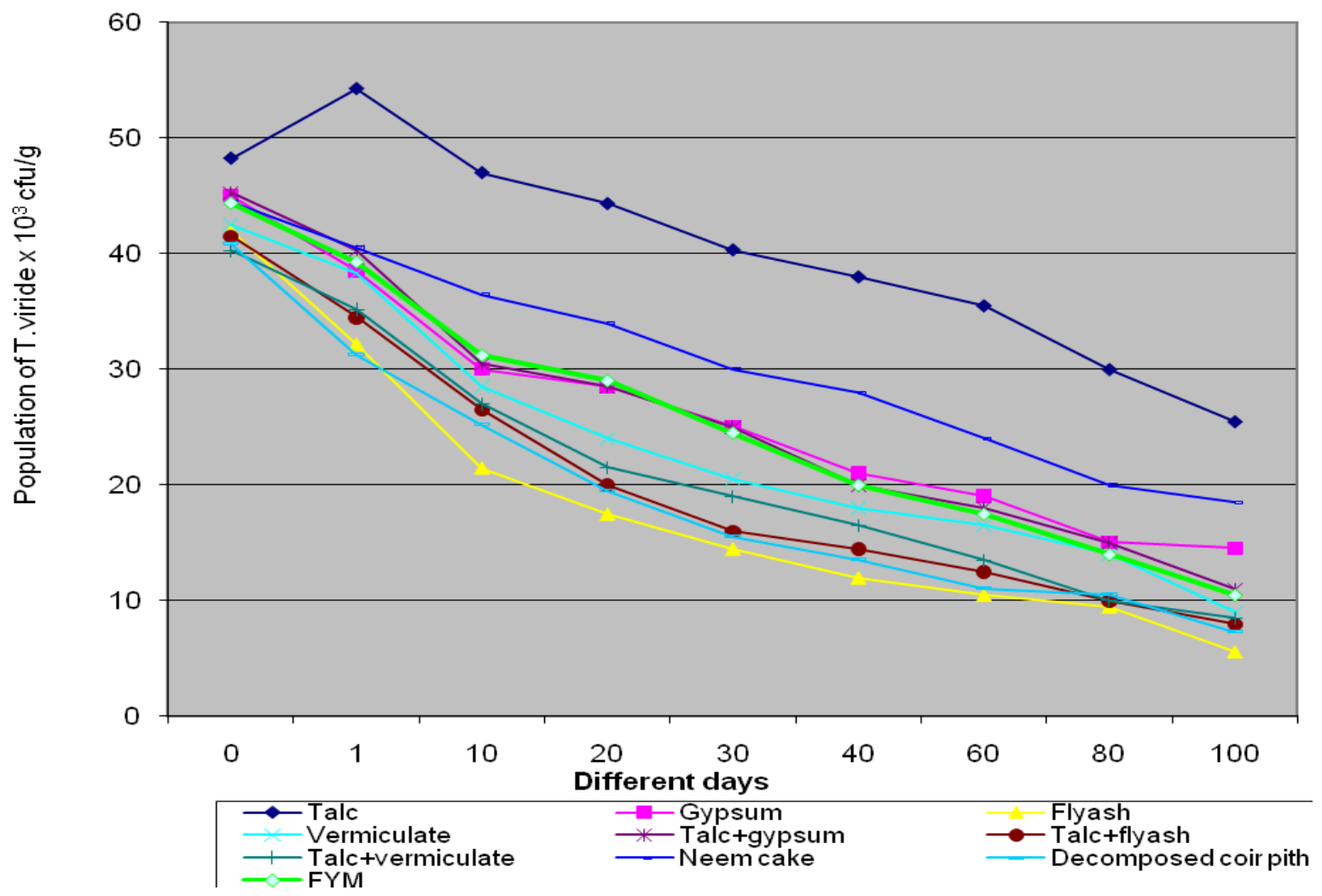


Table.2 Survivals of Bacillus subtilis in different carrier materials

\begin{tabular}{|c|c|c|c|c|c|c|c|c|c|c|}
\hline \multirow{3}{*}{$\begin{array}{c}\text { S. } \\
\text { No }\end{array}$} & \multirow[t]{3}{*}{ Carrier materials } & \multirow{2}{*}{\multicolumn{9}{|c|}{$\begin{array}{c}{ }^{*} \text { Survival of Bacillus subtilis in carrier materials } 1^{7} \mathrm{CFU} / \mathrm{g} \\
\text { Number of Davs (21 Davs after) }\end{array}$}} \\
\hline & & & & & & & & & & \\
\hline & & $\mathbf{0}$ & 20 & 30 & 40 & 50 & 60 & 70 & 80 & 90 \\
\hline 1 & Talc & 46.50 & 47.50 & 44.50 & 40.50 & 38.50 & 35.50 & 30.50 & 28.50 & 24.00 \\
\hline 2 & Gypsum & 42.33 & 43.00 & 38.00 & 34.50 & 30.00 & 24.50 & 21.00 & 18.75 & 12.33 \\
\hline 3 & ash & 41.5 & 40.50 & 37.50 & 34.50 & 27.50 & 23.00 & 20.00 & 15.50 & 9.50 \\
\hline 4 & Vermiculate & 42.50 & 43.60 & 40.50 & 37.50 & 35.00 & 31.50 & 26.50 & 24.00 & 18.50 \\
\hline 5 & Talc + Gypsum & 44.25 & 43.00 & 41.50 & 38.50 & 35.50 & 30.00 & 27.00 & 21.50 & 16.60 \\
\hline 6 & Talc +Flyash & 40.25 & 39.00 & 36.50 & 33.00 & 29.25 & 25.00 & 21.00 & 15.00 & 10.00 \\
\hline 7 & Talc +Vermiculate & 39.25 & 36.00 & 34.50 & 30.00 & 26.50 & 21.50 & 17.00 & 13.00 & 8.50 \\
\hline 8 & Talc + Neem cake & 41.50 & 40.00 & 38.00 & 35.50 & 31.50 & 27.50 & 24.50 & 20.50 & 16.50 \\
\hline 9 & Talc + Decomposed coir pith & 40.50 & 38.50 & 33.20 & 30.00 & 25.40 & 21.50 & 18.00 & 14.5 & 7.50 \\
\hline 10 & 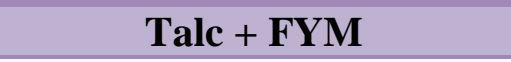 & 42.00 & 41.50 & 40.00 & 35.00 & 31.50 & 27.50 & 23.00 & 16.50 & 10.50 \\
\hline
\end{tabular}

*Mean of three replications

$\mathrm{CD}(\mathrm{P}=0.5)$

Carrier materials $\quad 0.780$

DAYS 0.780

Carrier materials x Days $\quad 2.469$

Fig.2 Survival of Pseudomonas fluorescens in different carrier materials

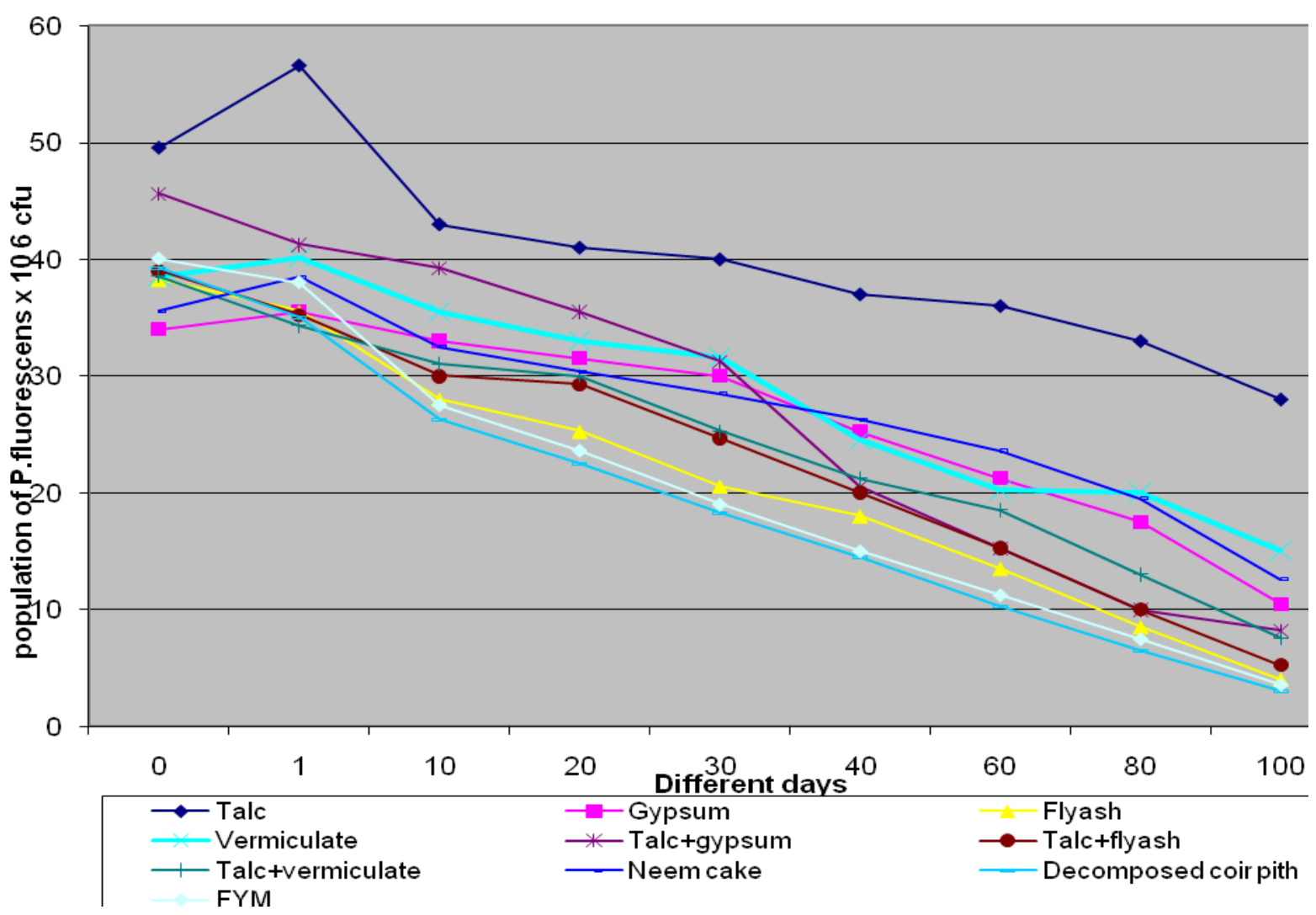




\section{References}

Jeyarajan, R., G. Ramakrishnan D. Dinakaran, and R. Sridhar, 1994. Development of product of Trichoderma viride and Bacillus subtilis for biocontrol of root rot disease. In: Biotechnology in India. Dwivedi, B.K. (ed.). Bioved. Res. Society, Allahabad, India, pp. 25-36.

Lewis, J. A., G.C. Papavizas and R.D. Lumsden. 1991. A new formulation system for the application of biocontrol fungi the biolistic method. Pl. Cell Rep., 12: $250-255$.

Loganathan, M., 2002. Development of bioformulation for the management of major fungal - nematode complex diseases of cabbage and cauliflower in Tamil Nadu. Ph.D. Thesis, Tamil Nadu Agricultural University, Coimbatore, India. Pp. 84-89.

Manav, M. and R. S. Singh. 2003. Shelf life of different formulations of mutant and parent strain of $T$. harzianum at variable temperatures. P1. Dis. Res., 18(2): 144146.

Manjula, K. and A.R. Podile. 2001. Chitin supplemented formulations improve biocontrol and plant growth promoting efficiency of Bacillus subtilis AF 1. Canadian J. Microbiol., 47(7): 618-625.

Paramasivan, M., A Chandrasekaran, S Mohan.2014. Ecological management of tropical sugar beet (TSB) root rot (Sclerotium rolfsii (Sacc.) by rhizosphere Trichoderma species Archives of Phytopathology and Plant Protection. 47 (13): 1629-1644.

Paramasivan, M., S Mohan, N Muthukrishnan 2007. Management of Coleus Dry Root Rot Pathogen, Macrophomina phaseolina by Fungal and Bacterial Antagonists. Indian Journal of Plant Protection. 35 (1) 133-135.

Prasad, R.D. and R. Rangeshwaran. 1999. Granular formulation of Trichoderma and Gliocladium spp. in biocontrol of Rhizoctonia salani of chickpea. J. Mycol. Pl. Pathol., 29: 222-226.

Prasad, R.D. and R. Rangeshwaran. 2000. Effect of soil application of a granular formulation of Trichoderma harzianum on Rhizoctonia solani incited seed rot and Damping off of Chickpea. J. Mycol. Pl. Pathol., 30: 216-220.

Ramakrishnan, G., R. Jeyarajan and D. Dinakaran. 1994. Talc based formulation of Trichoderma viride for bio control of Macrophomina phaseolina. J. Biol. Control., 8: 41-44.

Roiger, D.J. and S.N. Jeffers. 1991. Evaluation of Trichoderma spp. for biological control of Phytophthora crown and root rot of apple seedlings. Phytopathology, 81: 910-917.

Sangeetha Panickar. and R. Jeyarajan. 1993. Mass multiplication of biocontrol agent Trichoderma spp. Indian J. Mycol. Pl. Pathol., 23: 328-330.

Sangita Bapat and A. K. Shah. 2000. Biological control of Fusarial wilts of pigeon pea by Bacillus brevis. Can. J. Microbiol., 46:125-132.

Selvakumar, R., K.D. Srivastava, Rashmi Aggarwal and D.V. Singh. 2001. Development of bio formulation of Chaetomium globosum. Indian J. Microbial., 41: 93-95.

Sivakumar, G., R.C. Sharma and S.N. Rai. 2000. Biocontrol of banded leaf and sheath blight of maize by peat based Pseudomonas fluorescens formulation. Indian Phytopath., 53: 190-192.

Vidhyasekaran, P. and M. Muthamilan. 1995. Development of formulations of Pseudomonas fluorescens for control of chickpea wilt. Pl. Dis., 79: 782-786.

Vidhyasekaran, P. and M. Muthamilan. 1999. Evaluation of powder formulation of Pseudomonas fluorescens Pf1 for control of rice sheath blight. Biocontrol Sci. Tech., 9: 67-74. 
How to cite this article:

Paramasivan, M., S. Thaveedu, S. Mohan and Muthukrishnan, N. 2019. Survival ability of Trichoderma spp and Pseudomonas in Different carrier Materials. Int.J.Curr.Microbiol.App.Sci. 8(12): 1539-1546. doi: https://doi.org/10.20546/ijcmas.2019.812.184 